\title{
Temporal clustering of metals in a short sediment core of the Cascais Canyon (Portuguese Margin)
}

\author{
MÁRIO MIL-HOMENS ${ }^{1}$, ANA M. COSTA ${ }^{1}$, SUSANA M. LEBREIRO ${ }^{2}$, \\ JOÃO CANÁRIO ${ }^{3}$, CRISTINA LOPES ${ }^{1}$, FILOMENA MOURO ${ }^{4}$, MANUELA MATEUS $^{4}$, \\ HENKO DE STIGTER $^{5}$, THOMAS RICHTER ${ }^{5}$, VASCO BRANCO ${ }^{3}$, \\ M. ASCENSÃO TRANCOSO ${ }^{4}$, ZENAIDA MELO $^{4}$ and WIM BOER ${ }^{5}$
${ }^{1}$ Laboratório Nacional de Energia e Geologia, I.P., Unidade de Geologia Marinha, Estrada da Portela, Apartado 7586, 2721-866 Alfragide, Portugal. E-mail: mario.milhomens@ineti.pt
${ }^{2}$ Geological Survey of Spain, Dept. of Geosciences Research and Prediction - Global Change, c/ Ríos Rosas, 23, 28003-Madrid, Spain.
${ }^{3}$ Instituto National de Recursos Biológicos, Instituto de Investigação das Pescas e do Mar (IPIMAR), Av. Brasília, 1449-006 Lisboa, Portugal. ${ }^{4}$ Laboratório Nacional de Energia e Geologia, I.P., Laboratório de Análises Químicas, Azinhaga dos Lameiros,
1649-038 Lisboa, Portugal.
${ }^{5}$ Royal Netherlands Institute for Sea Research, Department of Marine Chemistry and Geology, P.O. Box 59, \\ 1790 AB Den Burg, Texel, The Netherlands.
}

\begin{abstract}
SUMMARY: The Cascais Canyon delivers contaminated sediments from the shelf to the deep marine environment. Multicore PE252-32, located at $2100 \mathrm{~m}$ water depth in the canyon, records the latest 300 years of sedimentation. It was dated by ${ }^{210} \mathrm{~Pb}$ and analyzed texturally and geochemically for major elements and selected trace metals $(\mathrm{Cu}, \mathrm{Cr}, \mathrm{Hg}, \mathrm{Li}, \mathrm{Ni}, \mathrm{Pb}$ and $\mathrm{Zn}$ ). Cluster analysis performed on the down-core geochemical data identified four groups of variables related by grain-size, geochemical source and composition. Mercury, $\mathrm{Pb}$ and $\mathrm{Zn}$ were grouped in a cluster representing the anthropogenic component. Cluster analysis was applied again particularly to the latter cluster relatively to depth, in order to constrain the onset and temporal evolution of anthropogenic contamination. A second clustering, made on the basis of $\mathrm{Hg}, \mathrm{Pb}$ and $\mathrm{Zn}$, grouped samples by age and degree of anthropogenic contamination. One cluster contained relatively uncontaminated samples older than $1900 \mathrm{AD}$, and another cluster samples younger than $1900 \mathrm{AD}$ with distinct metal enrichment. Maximum enrichments occurred during the early 1980 s, followed by a slight recovery from the mid-1980s to the present. Mercury was the element with the highest enrichment factor $(\mathrm{EFHg}=5)$. Despite relatively low accumulation rates at this core location, our results show the importance of the Cascais Canyon as a transport route for contaminated sediments from the Tagus prodelta into the deep regions of the Portuguese Margin.
\end{abstract}

Keywords: Portuguese Margin, Cascais Canyon, sediment, heavy metals, cluster analysis, enrichment factors.

RESUMEN: Cluster temporal de Metales En un testigo corto de Sedimento del Cañón Submarino de Cascais (Margen de Portugal). - El Cañón submarino de Cascais distribuye sedimentos contaminados de la plataforma continental al medio marino profundo. El testigo PE252-32, situado a 2100 metros de profundidad dentro del cañón, registra los últimos 300 años de su sedimentación. Se ha datado con ${ }^{210} \mathrm{~Pb}$ y ha sido analizada su granulometría, elementos mayoritarios y traza (cobre, cromo, mercurio, litio, níquel, plomo y zinc). Se ha llevado a cabo un análisis estadístico clúster, inicialmente aplicado a las series de datos geoquímicos en función de la profundidad, identificándose 4 grupos de variables, relacionados por la granulometría, procedencia y composición geoquímica. Los metales mercurio, plomo y zinc aparecen agrupados en un clúster que representa la componente antropogénica. A continuación el mismo análisis estadístico se aplicó específicamente a este grupo, en función de la profundidad, organizando las muestras según la edad de contaminación antropogénica. Como resultado las muestras quedan agrupadas en dos clústers principales, el de las muestras no contaminadas y más antiguas de 1900 AC, y el de las muestras más recientes de 1900 AC, marcando esta fecha el inicio de la contaminación por impacto de la actividad humana. Los máximos enriquecimientos ocurren durante el inicio de la década de los años ochenta, seguidos de un ligero descenso a partir de mediados de la misma década hasta la actualidad. De entre los demás, el mercurio es el elemento con el mayor grado de enriquecimiento $\left(\mathrm{EF}_{\mathrm{Hg}}=5\right)$. Aunque la tasa de acumulación de sedimentos en este lugar es 
relativamente baja, los resultados obtenidos ponen en evidencia la importancia del Cañón submarino de Cascais como vía de transporte de sedimentos contaminados depositados en el pro-delta del Tajo a las regiones profundas del margen de Portugal.

Palabras clave: margen de Portugal, cañón de Cascais, sedimentos, metales pesados, análisis estadístico, clúster, factores de enriquecimiento.

\section{INTRODUCTION}

Submarine canyons are important morphologic features cutting the seafloor of the Portuguese continental shelf and slope, and act as important conduits of natural and contaminated sediments from coastal areas to deeper parts of the ocean (de Stigter et al., 2007; Arzola et al., 2008; Lastras et al., 2009; Richter et al., 2009). Though they were more active during low sealevel stands, submarine canyons can maintain significant activity during the present state of high sea-level stands, particularly for fine sediment transport (van Weering et al., 2002; Palanques et al., 2006), resulting in high rates of fine-grained sediment deposition. This suggests that most canyons are currently accumulating rather than transporting sediments (de Stigter et al., 2007). However, very few studies have focused on the transfer of contaminants through submarine canyons (e.g. Ferrand et al., 1999; Paull et al., 2002; Palanques et al., 2008; Richter et al., 2009).

Intense industrial activity around the Tagus estuary (the most urbanized area of Portugal) has accompanied population growth during the $20^{\text {th }}$ century, and is thus responsible for releasing large quantities of metals into the estuary (e.g. Figuères et al., 1985; Vale, 1990; Araújo et al., 1998; Canário et al., 2005; Vale et al., 2008). Part of these metals was exported from the estuary and deposited on the adjacent shelf and slope, particularly in fine-grained deposits of the Tagus prodelta (Paiva et al., 1997; Jouanneau et

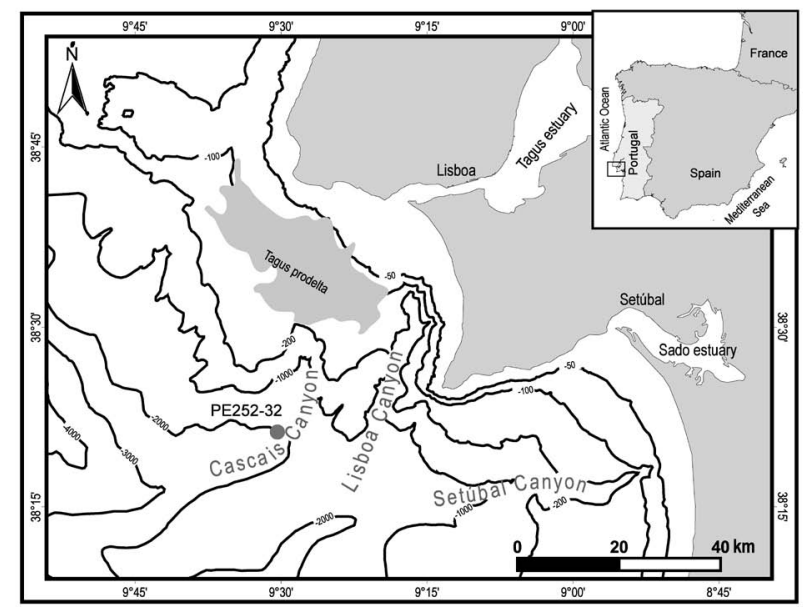

FIG. 1. - Location of multi-core site in the Cascais Canyon. Shading denotes the Tagus prodelta, characterized by sediment with more than $90 \%$ mud (silt + clay) and less than $30 \%$ of $\mathrm{CaCO}_{3}$ (data extracted from the Chart of Surface Sediments of the Portuguese shelf [sheet number 5], published by the Portuguese Hydrographic Institute [2005]). al., 1998; Queralt et al., 1999; Mil-Homens et al., 2009a; Mil-Homens et al., 2009b), and the LisboaSetúbal canyon system (Richter et al., 2009). The Cascais Canyon also emerges as an important target for assessing the transfer of contaminated shelf sediments to abyssal plains due to its proximity to these contaminated areas. The main goal of this study was to assess the temporal evolution and current level of contaminant enrichment for sediments of the middle Cascais Canyon. Cluster analysis (CA) of geochemical analytical data was performed to assess the history of deposition of major and selected trace elements $(\mathrm{Cu}, \mathrm{Cr}, \mathrm{Hg}, \mathrm{Li}, \mathrm{Ni}, \mathrm{Pb}$ and $\mathrm{Zn})$. This paper focuses only on one site within the Cascais Canyon, which appears to be representative of the transport of contaminated sediments through the canyon. A broader and promising study, in which a series of cores along the canyon are used to reconstruct the last 300 years of sediment transport and deposition, is in progress.

\section{MATERIALS AND METHODS}

\section{Sampling}

Multi-core PE252-32 $\left(8.36307^{\circ} \mathrm{N}\right.$ and $9.50690^{\circ} \mathrm{W}$; $2100 \mathrm{~m}$ water depth, $37 \mathrm{~cm}$ in length) was collected during cruise 64PE252 of the Dutch RV Pelagia. In the geomorphological context of the Cascais Canyon (Lastras et al., 2009), this multi-core was recovered at the thalweg of the main branch of the Cascais Canyon (Fig. 1), one of the shortest canyons on the western Portuguese Margin. It starts at around $175 \mathrm{~m}$ water depth in the shelf area adjacent to the Tagus prodelta, southwest of the Tagus estuary mouth, and extends down to the Tagus abyssal plain to water depths exceeding $4600 \mathrm{~m}$.

We used one sub-core of multicore PE252-32 that was kept refrigerated at approximately $2^{\circ} \mathrm{C}$ before being opened, described, photographed and $\mathrm{x}$-rayed to characterize the sediment lithology and to identify its sedimentological and biological structures. This subcore was sampled using cut-off syringes or sliced at 0.5 or $1 \mathrm{~cm}$ intervals in the laboratory, and samples were freeze-dried.

\section{Grain-size}

Grain-size distributions were determined with a Coulter LS230 laser particle analyzer after sample disaggregation by ultra-sonication. These measurements were carried out for 12 sample intervals also used for ${ }^{210} \mathrm{~Pb}$ determinations. 


\section{Core dating}

The sediment core was dated through the vertical distribution of excess ${ }^{210} \mathrm{~Pb}\left({ }^{210} \mathrm{~Pb}\right.$ xs $)$, which is incorporated in the accumulating sediment from atmospheric fallout by decay of ${ }^{226} \mathrm{Ra}$ in the water column and indirectly by rivers (Cundy and Croudace, 1995; Boer et al., 2006). ${ }^{210} \mathrm{~Pb}$ was determined by alpha-spectrometry with Canberra Passivated Implanted Planar Silicon (PIPS) detectors using the grand-daughter isotope ${ }^{210} \mathrm{Po}$ (with a half-life of 138.4 days) after sediment samples were spiked with ${ }^{209} \mathrm{Po}$ and leached with $\mathrm{HCl}$, following the procedure described by Boer et al. (2006). ${ }^{210} \mathrm{~Pb}$ has a half-life of $22.3 \mathrm{yrs}$, thus being very useful for reconstructing the last 100-150 years of sediment deposition, which is $c a .5$ times the half-life of the isotope (Valette-Silver, 1993). Sediment age was determined on the basis of the downcore ${ }^{210} \mathrm{~Pb}$ profile, fitted with the CF/CS (constant flux/constant sedimentation) model (Boer et al., 2006), in which a constant accumulation rate and negligible bioturbation are assumed.

\section{Major and trace elements}

Major elements (presented here as oxides $\mathrm{SiO}_{2}$, $\mathrm{Al}_{2} \mathrm{O}_{3}, \mathrm{Fe}_{2} \mathrm{O}_{3}, \mathrm{MgO}, \mathrm{CaO}, \mathrm{Na}_{2} \mathrm{O}, \mathrm{K}_{2} \mathrm{O}, \mathrm{TiO}_{2}$ and $\mathrm{MnO}$ ) were determined on fusion beads by WD-XRFS, using a sequential wavelength dispersive spectrometer (model AXIOS), according to an in-house LNEG-LAQ methodology. After being oven-dried for two hours at $105^{\circ} \mathrm{C}$, samples and standards were prepared as glass beads as follows: $1000 \mathrm{mg}$ of sample were mixed with $9.0 \mathrm{~g}$ of lithium tetraborate flux $\left(\mathrm{Li}_{2} \mathrm{~B}_{4} \mathrm{O}_{7}\right)$ and $20 \mathrm{mg}$ of ammonium iodide $\left(\mathrm{NH}_{4} \mathrm{I}\right)$. This mixture was fused in Pt95-Au5 crucibles at $1150{ }^{\circ} \mathrm{C}$ for 20 minutes and then poured into Pt-Au dishes. The calibration curves were constructed using a set of 16 standards (National Research Centre for CRM's, Beijing, China) with a range of analytes and matrices similar to those of the samples. To correct for matrix interferences, theoretical $\alpha$ correction factors were applied. According to the laboratory quality control procedures, the calibrations were validated by daily analysis of certified reference material (CRM).

Total trace elements $(\mathrm{Cu}, \mathrm{Cr}, \mathrm{Ni}, \mathrm{Li}, \mathrm{Pb}$ and $\mathrm{Zn})$ were measured by flame atomic absorption spectrometry (FAAS) after total acid digestion of sediment samples following the procedure described by Alves et al. (2009). An amount of $0.25 \mathrm{~g}$ of freeze-dried and ground sample was mixed with $2.5 \mathrm{ml}$ of $\mathrm{HNO}_{3}\left(\mathrm{HNO}_{3}\right.$ Suprapur $65 \%), 2.5 \mathrm{ml}$ of $\mathrm{HClO}_{4}\left(\mathrm{HClO}_{4}\right.$ Suprapur $70 \%$ ) and $5 \mathrm{ml}$ of HF (HF Suprapur $40 \%$ ) on a Teflon beaker with lid. The mixture was heated for 15 minutes on an electric hotplate, followed by evaporation until dryness. After that, $5 \mathrm{ml}$ of hot Milli-Q water (>18 mOhm), $5 \mathrm{ml}$ of $\mathrm{HNO}_{3}$ and $2.5 \mathrm{ml}$ of $\mathrm{HClO}_{4}$ were added to the solution and it was heated again on the electric hotplate and evaporated until dryness. The residue was dissolved with $5 \mathrm{ml}$ of hot Milli-Q water
(>18 $\mathrm{mOhm}$ ) and $5 \mathrm{ml}$ of $\mathrm{HNO}_{3}$ for solubilization of salts. This procedure was repeated (usually twice) until the solutions were clear and transparent. After cooling down, the solution was transferred to a $50 \mathrm{ml}$ volumetric flask and diluted to this volume with Milli-Q water.

Throughout the entire procedure blank reagent and CRM were regularly measured. Analytical precision expressed as relative standard deviation (RSD) of 8 replicates of MESS-3 (NRCC - Canada) was nominally lower than $10 \%(P<0.05)$. Accuracies determined by comparing results on CRM MESS-3 with certified values were within 7\%. All FAAS measurements were performed on a SOLAAR 969 AA Thermo Elemental spectrometer equipped with a deuterium lamp background correction system, using hollow-cathode lamps from the Thermo Electron Corporation (Cambridge, UK) as radiation source at each element.

Total Hg was measured by atomic absorption spectrometry using a Leco AMA-254 silicon UV diode detector, after pyrolysis of each sample (approximately $0.05 \mathrm{~g}$ ) in a combustion tube at $750^{\circ} \mathrm{C}$ under an oxygenrich atmosphere, and collection on a gold amalgamator (Costley et al., 2000). Precision of Hg measurements, expressed as RSD of 4 replicate samples of the CRM MESS-3, was less than $4 \%(P<0.05)$. Based on the mean values of the CRM, the results for $\mathrm{Hg}$ (4 replicates) indicate an accuracy of $106 \%$.

\section{Statistical Analysis}

We used the multivariate statistical method of cluster analysis (CA) following Ward's criterion (Davis, 2002) in order to relate analyses of variance. This allowed us to evaluate the similarity between the two variables (major and trace elements in a total of 16) and samples (corresponding to 19 depths), classifying them into relatively homogeneous meaningful clusters. CA was applied to identify both element associations and major changes in chemical composition through time (core depth). CA was performed using the SPSS software (version 13 for Windows) and was carried out on the standardized datasets (whose mean and standard deviation were set to zero and one, respectively - $\mathrm{Z}$ score) to minimize the effect by the difference in measured units, or variance, and to render the data dimensionless.

In addition we also used Spearman's correlations $(r)$ in order to identify significant statistical correlations among the measured element variables (Davis, 2002).

\section{Enrichment Factors (EF)}

The impact of anthropogenic-derived metals was estimated based on the determination of enrichment factors $(\mathrm{EF})$. EF were calculated as the ratio between the normalized sample and background (metal/conservative element) to reduce grain-size effects $[\mathrm{EF}=$ (metal/ conservative element) $)_{\text {sample }} /$ (metal/ element 
conservative) $\left.)_{\text {background }}\right]$. We considered the average concentrations from the three bottom samples of the core studied as local background values, because these samples comprise the local or regional variability. According to the ${ }^{210} \mathrm{~Pb}$ chronology, these samples reflect pre-industrial deposition and thus represent the metal concentration free of contamination.

\section{RESULTS}

\section{Grain-size and chemical composition}

At $2 \mathrm{~cm}$ (core depth), core PE252-32 shows a thin (ca. $1 \mathrm{~cm}$ ), dark-brown oxidized layer (10YR 3/4, Munsell soil colour chart). Underneath this layer, a gradual change in colour is observed down-core from dark olive (5Y 4/3, Munsell soil colour chart) to olive-black (5Y 3.5/2, Munsell soil colour chart). No visible trace of bioturbation was observed. The sediments were mainly composed of the fine-grained size fraction $(<63$ $\mu \mathrm{m})$, ranging between $89 \%$ and $99 \%$. Fine contents are constant in the top $10 \mathrm{~cm}$, with values of $\mathrm{ca} .42 \%$ of clay and $56 \%$ of silt, decreasing towards the bottom down to $32 \%$ and $53 \%$, respectively (Fig. 2). Sand content is very low $(<4 \%)$, except for the bottom two measured samples (depths 29-30 and 34-35 cm) with sand percentages of $8 \%$ and $14 \%$, respectively.

Silica $\left(\mathrm{SiO}_{2}\right)$ is the most abundant oxide, ranging from $38 \%$ to $46 \%$. Except for the top $10 \mathrm{~cm}$ and bottom $7 \mathrm{~cm}$, $\mathrm{SiO}_{2}$ and $\mathrm{CaO}$ show similar general trends in depth, decreasing gradually from bottom to top. This trend is op-

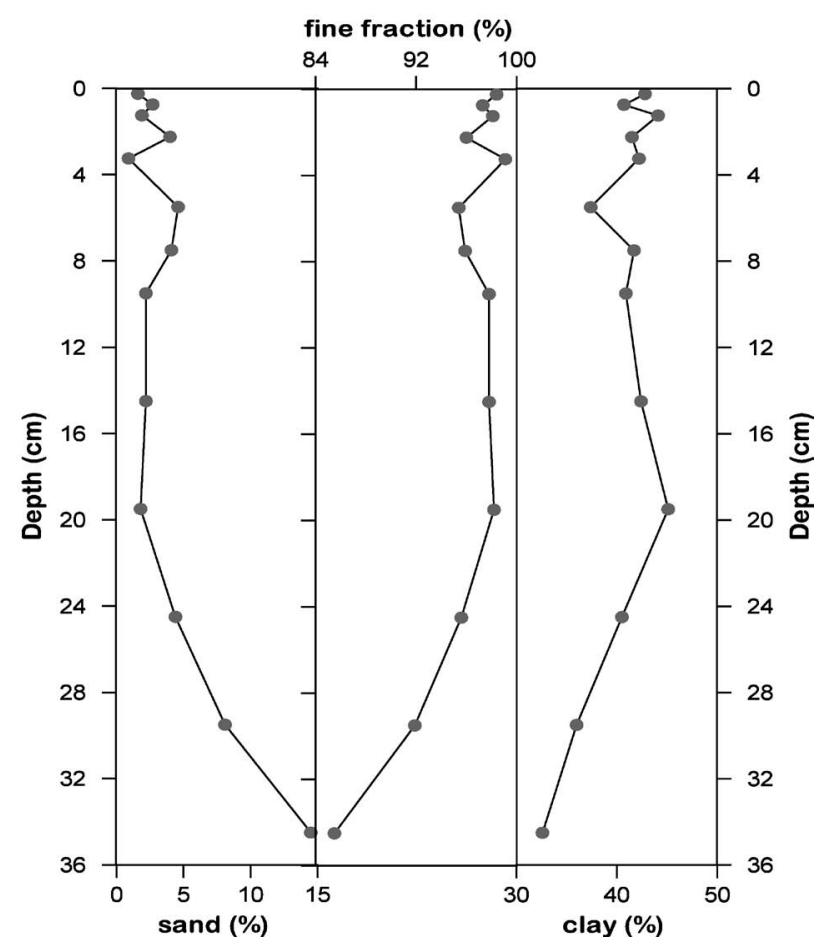

FIG. 2. - Vertical distribution of grain-size fractions (clay, fine fraction $[<63 \mu \mathrm{m}]$, sand) in sediment core PE252-32. posed to alumina $\left(\mathrm{Al}_{2} \mathrm{O}_{3}\right)$. Above $10 \mathrm{~cm}$ core depth, $\mathrm{SiO}_{2}$ and $\mathrm{Al}_{2} \mathrm{O}_{3}$ both show a slight decrease $(\mathrm{n}=10, P=0.08$; $r=0.58)$ towards the surface, unlike $\mathrm{CaO}$ which increases slightly (Fig. 3). Thus, below $10 \mathrm{~cm}$ depth, the lithology is mainly siliceous-aluminosilicated, with increasing $\mathrm{CaO}$ towards the bottom. In the bottom $6 \mathrm{~cm}$ of the core, high contents of $\mathrm{CaO}, \mathrm{SiO}_{2}$ and sand (Figs. 2 and 3) suggest the presence of abundant quartz and carbonate sand. The higher silica content reflects dominant quartz grains in the bottom sample. Alumina, $\mathrm{K}_{2} \mathrm{O}, \mathrm{MgO}, \mathrm{TiO}_{2}, \mathrm{Cr}$ and Li profiles show similar down-core variations. Manganese oxide ( $\mathrm{MnO}$ ), $\mathrm{Fe}_{2} \mathrm{O}_{3}$, and $\mathrm{Cu}$ (Fig. 3) profiles exhibit a subsurface peak (at about $2 \mathrm{~cm}$ ) coinciding with the oxidized layer. Below this level, $\mathrm{MnO}$ shows very homogeneous contents, while $\mathrm{Fe}_{2} \mathrm{O}_{3}$ is comparable with $\mathrm{Al}_{2} \mathrm{O}_{3}$. Zinc, $\mathrm{Cu}, \mathrm{Ni}, \mathrm{Pb}, \mathrm{Hg}$ and $\mathrm{Na}_{2} \mathrm{O}$ show a very similar down-core behaviour. This trend is marked by a continuous increase towards the present day, followed by slightly decreasing concentrations in the top $2 \mathrm{~cm}$. Clearly, there is a significant positive relationship among these element concentrations (Table 1). This set of elements $(\mathrm{Cu}, \mathrm{Hg}$, $\mathrm{Ni}, \mathrm{Pb}, \mathrm{Zn}$ and $\mathrm{Na}_{2} \mathrm{O}$ ) is also characterized by high and significant values of Spearman's correlation coefficients (r) with $\mathrm{MnO}$ and $\mathrm{Fe}_{2} \mathrm{O}_{3}$. However, considering only the top 10 samples, the Spearman's correlation coefficients $(r)$ were not significant between $\mathrm{MnO}, \mathrm{Hg}$ and $\mathrm{Pb}(\mathrm{n}=10$; $P=0.07 \mathrm{MnO}$ vs $\mathrm{Hg} r=0.60, \mathrm{MnO}$ vs $\mathrm{Pb} r=0.60)$ and $\mathrm{Hg}$ and $\mathrm{Pb}$ with $\mathrm{Fe}\left(\mathrm{n}=10 ; P=0.5, \mathrm{Fe}_{2} \mathrm{O}_{3}\right.$ vs $\mathrm{Hg} r=0.26, P=0.3$, $\mathrm{Fe}_{2} \mathrm{O}_{3}$ vs $\left.\mathrm{Pb} r=0.37\right)$. In this interval, $\mathrm{Cu}$ and $\mathrm{Ni}$ show significant correlations with $\mathrm{MnO}(\mathrm{n}=10 ; P<0.01 \mathrm{MnO}$ vs $\mathrm{Cu} r=0.87$, $\mathrm{MnO}$ vs Ni $r=0.79$ ) and are also not significantly correlated with $\mathrm{Fe}\left(\mathrm{n}=10 ; P>0.06 \mathrm{Fe}_{2} \mathrm{O}_{3}\right.$ vs $\mathrm{Cu} r=0$. $61, \mathrm{Fe}_{2} \mathrm{O}_{3}$ vs $\mathrm{Ni} r=0.59$ ).

Silica shows a significant negative correlation with $\mathrm{Fe}_{2} \mathrm{O}_{3}, \mathrm{MnO}, \mathrm{Na}_{2} \mathrm{O}, \mathrm{Zn}, \mathrm{Cu}, \mathrm{Ni}, \mathrm{Pb}$ and $\mathrm{Hg}$. Alumina and $\mathrm{Li}$ show no significant linear association with $\mathrm{Zn}, \mathrm{Cu}$, $\mathrm{Pb}$ and $\mathrm{Hg}$ (Table 1). However, considering the samples below the top $10 \mathrm{~cm}$, where all these elements display similar down-core trends, there is a positive correlation between them ( $\mathrm{n}=9$ and $P<0.01 \mathrm{Al}_{2} \mathrm{O}_{3}$ vs $\mathrm{Cu} r=0.97$, Li vs $\mathrm{Cu} r=0.78 ; \mathrm{Li}$ vs Ni $r=0.88 ; \mathrm{Al}_{2} \mathrm{O}_{3}$ vs $\mathrm{Zn} r=0.82$, Li vs $\mathrm{Zn}$ $r=0.92 ; \mathrm{Al}_{2} \mathrm{O}_{3}$ vs $\mathrm{Pb} r=0.83 ; \mathrm{Al}_{2} \mathrm{O}_{3}$ vs $\mathrm{Hg} r=0.92 ; P<0.05$ $\mathrm{Li}$ vs $\mathrm{Hg} r=0.70, \mathrm{Al}_{2} \mathrm{O}_{3}$ vs $\mathrm{Ni} r=0.70 ; P=0.09 \mathrm{Li}$ vs $\mathrm{Pb}$ $r=0.60)$, suggesting a detrital origin. The absence of any relationship between $\mathrm{Hg}, \mathrm{Pb}$ and $\mathrm{Zn}$ and the elements normally associated with aluminosilicates suggests that core samples above $10 \mathrm{~cm}$ depth have enrichments unrelated to the fine-grained sediment components (Fig. 4). Copper has a similar behaviour to $\mathrm{Hg}, \mathrm{Pb}$ and $\mathrm{Zn}$, showing a small variation between the two sets of samples (Fig. 4). In the case of $\mathrm{Ni}$ and $\mathrm{Cr}$, this differentiation is not so clear suggesting that both elements have a detrital origin (Fig. 4).

\section{Age model}

The sediment accumulation rate of ${ }^{210} \mathrm{~Pb}$, in $\mathrm{g} \mathrm{cm}^{-2}$ $\mathrm{yr}^{-1}$ (Fig. 5) was calculated by transforming the depth scale into cumulative dry mass (CMD) using the dry bulk density in order to correct compactation (Robbins, 

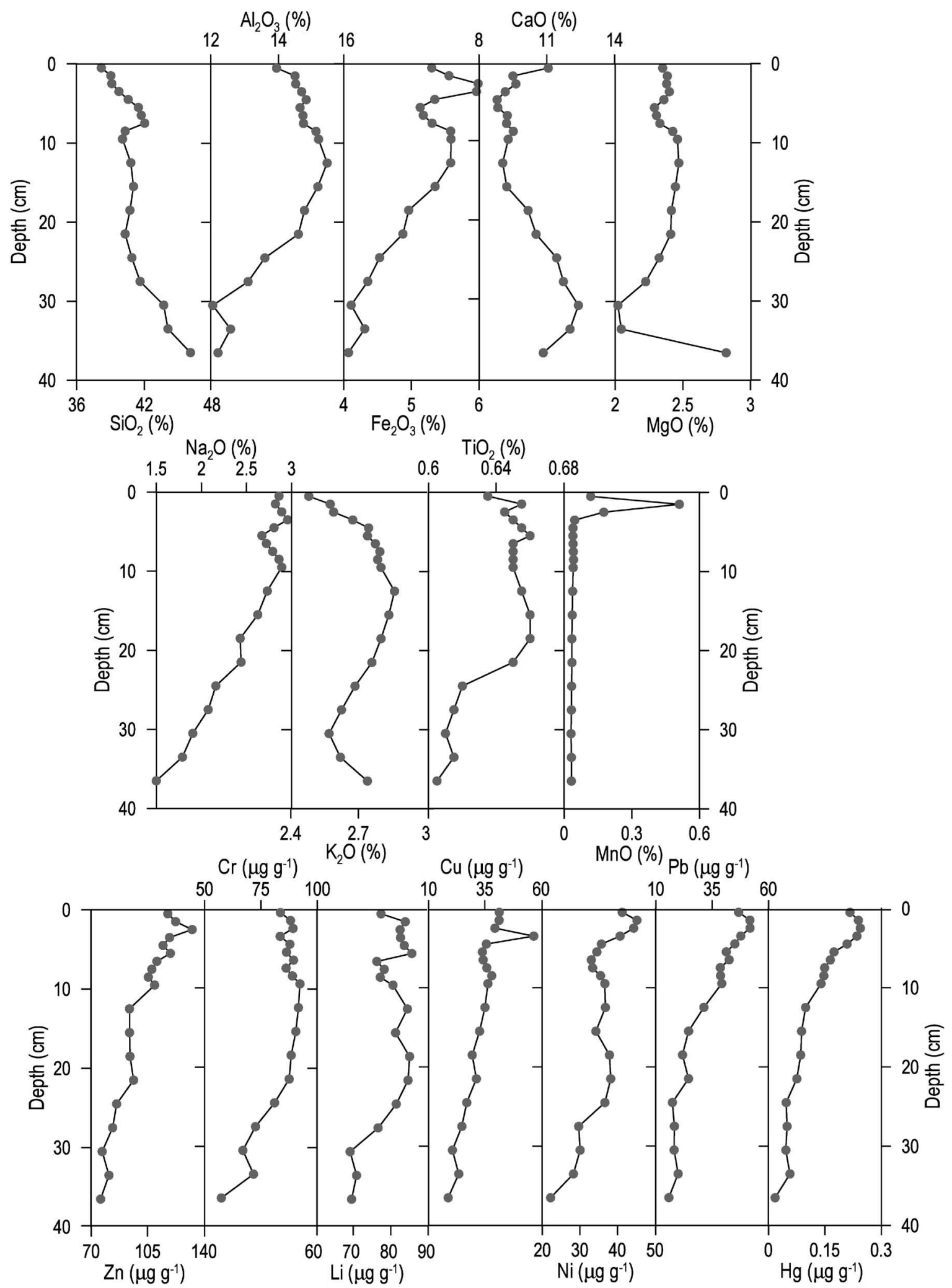

FIG. 3. - Profiles of major (\%) and trace elements $\left(\mu \mathrm{g} \mathrm{g}^{-1}\right)$ in sediment core PE252-32.

1978; Appleby and Oldfield, 1992). The ${ }^{210} \mathrm{~Pb}$ profile showed a regular exponential decrease towards the bottom. Two samples from the nearest levels, where a fragment of synthetic rock (sinter probably dumped from a ship) was found, were not considered for defining sediment accumulation rates. Nevertheless, the 

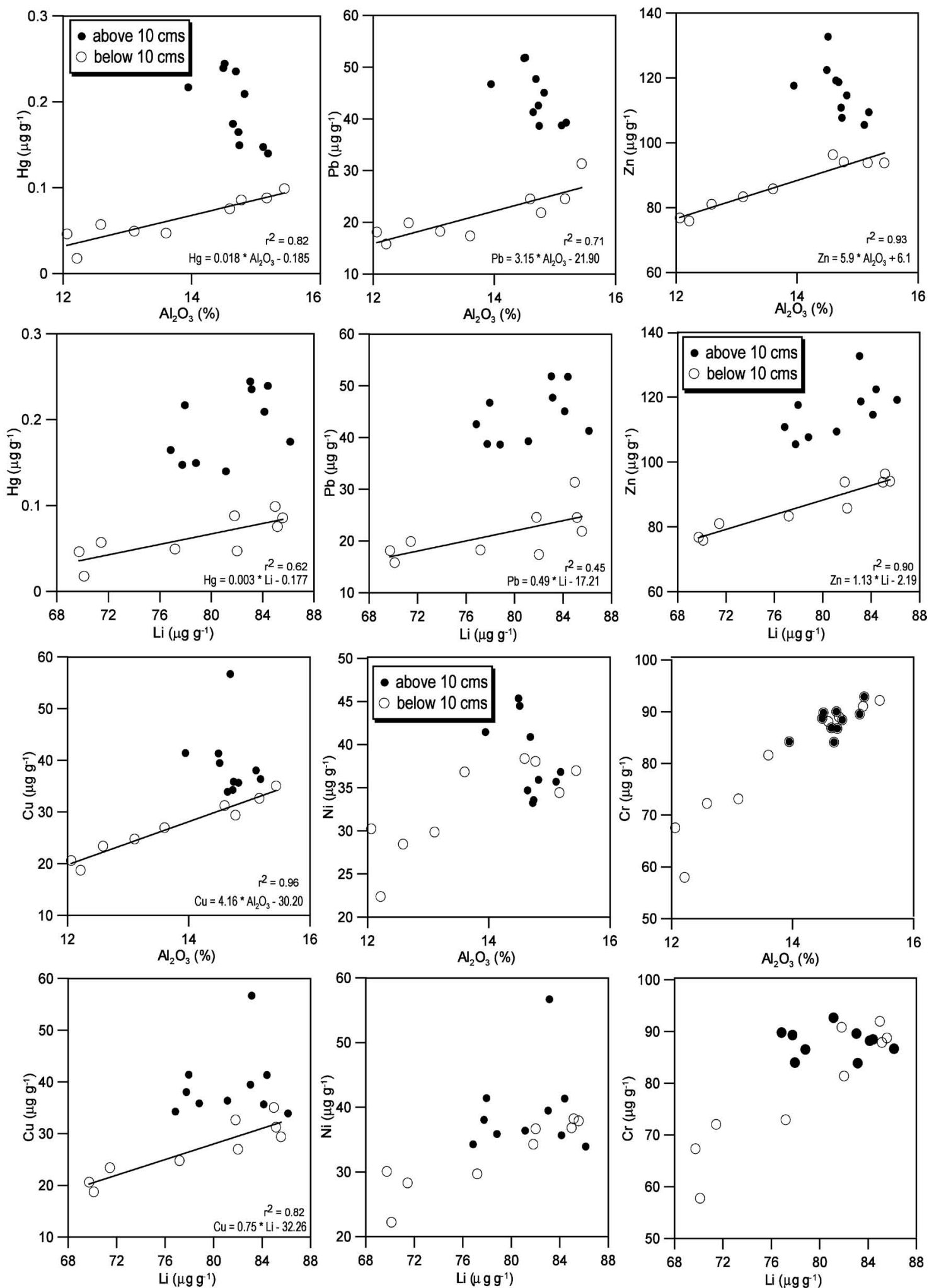

FIG. 4. - Relationship between metals ( $\mathrm{Hg}, \mathrm{Pb}, \mathrm{Zn}, \mathrm{Cu}, \mathrm{Ni}$ and $\mathrm{Cr}$ ) and $\mathrm{Al}_{2} \mathrm{O}_{3}$, and $\mathrm{Li}$ in down-core samples of core PE252-32. Sediment samples from the top $10 \mathrm{~cm}$ are represented by filled symbols.

sinter fragment in the core may actually support the age model, because it seems to correspond to a period (first half of the $20^{\text {th }}$ century) when steam ships may have passed over the core site. The obtained sediment accumulation was $0.061 \mathrm{~g} \mathrm{~cm}^{-2} \mathrm{yr}^{-1}$, equivalent to an average linear sedimentation rate of $0.11 \mathrm{~cm} \mathrm{yr}^{-1}$. 
TABLE 1. - Spearman's correlation matrix for the studied variables of core PE252-32 (19 samples).

\begin{tabular}{|c|c|c|c|c|c|c|c|c|c|c|c|c|c|c|c|c|}
\hline & $\mathrm{SiO}_{2}$ & $\mathrm{Al}_{2} \mathrm{O}_{3}$ & $\mathrm{Fe}_{2} \mathrm{O}_{3}$ & $\mathrm{MgO}$ & $\mathrm{CaO}$ & $\mathrm{Na}_{2} \mathrm{O}$ & $\mathrm{K}_{2} \mathrm{O}$ & $\mathrm{TiO}_{2}$ & $\mathrm{MnO}$ & $\mathrm{Cr}$ & $\mathrm{Cu}$ & $\mathrm{Ni}$ & $\mathrm{Li}$ & $\mathrm{Zn}$ & $\mathrm{Pb}$ & $\mathrm{Hg}$ \\
\hline $\mathrm{SiO}_{2}$ & 1.00 & & & & & & & & & & & & & & & \\
\hline $\mathrm{Al}_{2} \mathrm{O}_{3}$ & -.31 & 1.00 & & & & & & & & & & & & & & \\
\hline $\mathrm{Fe}_{2}^{2} \mathrm{O}_{3}^{3}$ & $-.70 * *$ & $.69 * *$ & 1.00 & & & & & & & & & & & & & \\
\hline $\mathrm{MgO}^{2}$ & -.34 & $.57 *$ & .45 & 1.00 & & & & & & & & & & & & \\
\hline $\mathrm{CaO}$ & .22 & $-.76 * *$ & $-.64 * *$ & -.34 & 1.00 & & & & & & & & & & & \\
\hline $\mathrm{Na}_{2} \mathrm{O}$ & $-.79 * *$ & $.54 *$ & $.92 * *$ & .29 & $-.56 *$ & 1.00 & & & & & & & & & & \\
\hline $\mathrm{K}_{2} \mathrm{O}$ & .14 & $.83 * *$ & .26 & $.59 * *$ & $-.54 *$ & .05 & 1.00 & & & & & & & & & \\
\hline $\mathrm{TiO}_{2}$ & -.33 & $.77 * *$ & $.50 *$ & .35 & $-.77 * *$ & .36 & $.59 * *$ & 1.00 & & & & & & & & \\
\hline $\mathrm{MnO}$ & $-.75^{* *}$ & .40 & $.83^{* *}$ & .22 & $-.51 *$ & $.93 * *$ & -.06 & .37 & 1.00 & & & & & & & \\
\hline $\mathrm{Cr}$ & -.45 & $.85^{* *}$ & $.72 * *$ & $.51 *$ & $-.58 * *$ & $.56^{*}$ & $.64 * *$ & $.69 * *$ & $=.50 *$ & 1.00 & & & & & & \\
\hline $\mathrm{Cu}$ & $-.80 * *$ & $.46^{*}$ & $.87 * *$ & .24 & $-.53 *$ & $.97 * *$ & -.04 & .37 & $.97 * *$ & $.48 *$ & 1.00 & & & & & \\
\hline $\mathrm{Ni}$ & $-.92 * *$ & .26 & $.62 * *$ & .30 & -.23 & $.67 * *$ & -.12 & .39 & $.68^{* *}$ & .40 & $.71 * *$ & 1.00 & & & & \\
\hline $\mathrm{Li}$ & $-.52 *$ & $.46^{*}$ & .40 & .29 & $-.56^{*}$ & .32 & .30 & $.77 * *$ & .31 & .43 & .33 & $.68 * *$ & 1.00 & & & \\
\hline $\mathrm{Zn}$ & $-.71 * *$ & .31 & $.70^{* *}$ & .01 & $-.57 *$ & $.83 * *$ & -.15 & $.48 *$ & $.89 * *$ & . 44 & $.85^{* *}$ & $.68 * *$ & $.51 *$ & 1.00 & & \\
\hline $\mathrm{Pb}$ & $-.71 * *$ & .36 & $.79 * *$ & .06 & $-.57 *$ & $.88 * *$ & -.15 & .43 & $.92 * *$ & $.49 *$ & $.91 * *$ & $.64 * *$ & .37 & $.95^{* *}$ & 1.00 & \\
\hline $\mathrm{Hg}$ & $-.59 * *$ & .37 & $.71 * *$ & .03 & $-.56 *$ & $.78 * *$ & -.05 & $.46 *$ & $.86 * *$ & $.46 *$ & $.83^{* *}$ & $.61 * *$ & .39 & $.88^{* *}$ & $.91 * *$ & 1.00 \\
\hline
\end{tabular}

** Correlation is significant at the 0.01 level (2-tailed).

* Correlation is significant at the 0.05 level (2-tailed).

\section{Statistical analysis}

The cluster analysis (hierarchical clustering, Ward's method, squared Euclidean distance; Davis, 2002) of 16 variables is illustrated by the dendrogram in Figure 6. Distance on the horizontal axis represents the level

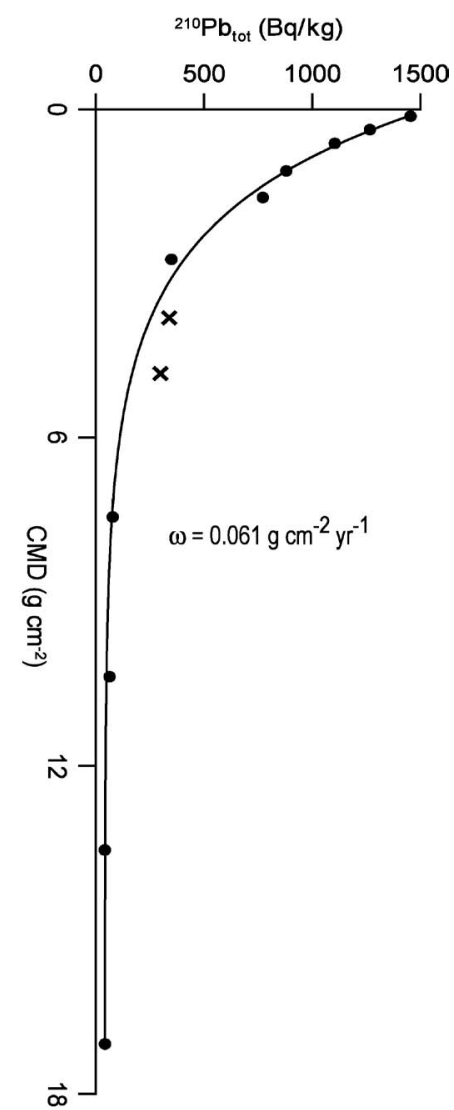

FIG. 5. - Vertical distribution of ${ }^{210} \mathrm{~Pb}$ in core PE252-32 plotted against cumulative mass depth (CMD). Crosses represent ${ }^{210} \mathrm{~Pb}$ values not considered for determination of sediment accumulation rates. of association between groups of variables (Davis, 2002). Low distance values indicate greatest similarity between variables (Davis, 2002). The variables fall into four main clusters (A, B, C and D) that seem to have a geochemical implication in terms of sediment composition and element sources. The high proximity between clusters A and B suggests that their components represent the fine fraction of sediments. While cluster B contains elements ( $\mathrm{Al}, \mathrm{Ti}$ and $\mathrm{Li}$ ) commonly associated with the detrital fine fraction of sediments, cluster A also includes elements typically associated with natural elements connected with diagenesis (Mn, $\mathrm{Fe})$ and other elements $(\mathrm{Pb}, \mathrm{Zn}, \mathrm{Hg}, \mathrm{Cu}, \mathrm{Ni})$ that may also have a natural origin, or can be derived from diagenetic processes or from anthropogenic sources. This association suggests that $\mathrm{Fe}$ and $\mathrm{Mn}$ oxide-hydroxides are probably controlling (totally or partially) their distributions in sediments. This cluster can be separated into two subgroups $\left(A_{1}\right.$ and $\left.A_{2}\right)$. Subgroup $A_{2}$ is formed only by $\mathrm{Mn}$, which indicates that this element has a

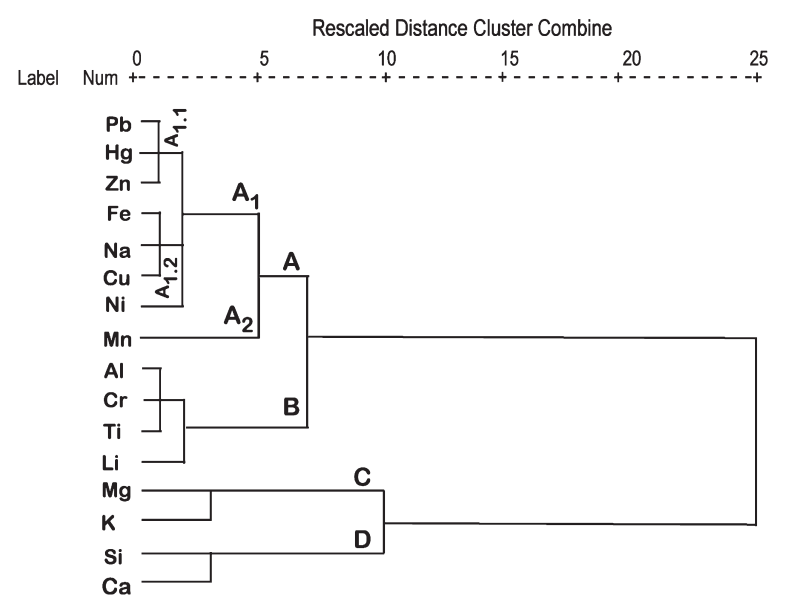

FIG. 6. - Hierarchical dendrogram for 16 variables obtained by cluster analysis (Ward's method of linkage, squared Euclidean distance). 


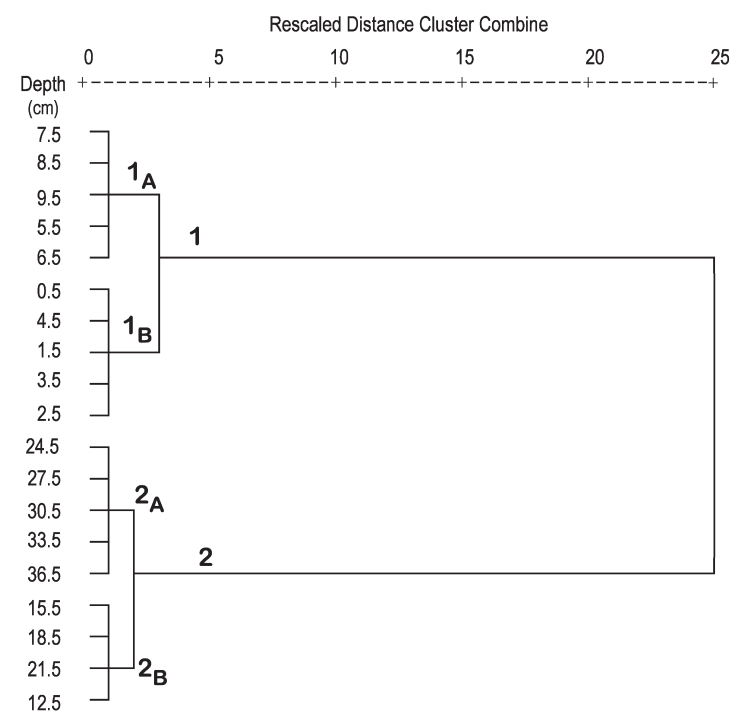

FIG. 7. - Hierarchical dendrogram (Ward's method of linkage, squared Euclidean distance) for 19 down-core samples using as clustering variables the subgroup composed of $\mathrm{Hg}, \mathrm{Pb}$ and $\mathrm{Zn}$, interpreted as reflecting anthropogenic contributions.

specific distribution pattern compared with the other elements. The association between $\mathrm{Zn}, \mathrm{Pb}$ and $\mathrm{Hg}$ in subgroup $\mathrm{A}_{111}$ is interpreted as having a predominantly anthropogenic origin, while $\mathrm{Cu}$ and $\mathrm{Ni}$ (other elements commonly related to anthropogenic activities) are grouped together with $\mathrm{Fe}$ (subgroup $\mathrm{A}_{1.2}$ ). The proximity between clusters $\mathrm{C}$ and $\mathrm{D}$ is interpreted as representing bio-lithoclastic sands. Cluster $\mathrm{C}$ includes $\mathrm{K}$ and $\mathrm{Mg}$, indicating the occurrence of both K-feldspars and high-Mg calcite in the basal samples. Cluster D includes $\mathrm{Si}$, and $\mathrm{Ca}$, which is interpreted as dominance of quartz and carbonates in the sand.

Based on the clustering of $\mathrm{Pb}, \mathrm{Hg}$ and $\mathrm{Zn}\left(\mathrm{A}_{1.1}\right.$ anthropogenic component of the sediments), cluster analysis was again applied relatively to sample depths, with the main goal of classifying the sample levels in terms of timing of anthropogenic contamination. Figure 7 shows the dendrogram produced by clustering 19 samples. The applied CA method is the same as before. The samples fall into two main clusters (1 and 2) with a stratigraphically consistent pattern. Cluster 1 includes the top $10 \mathrm{~cm}$ (since $c a .1900 \mathrm{AD}$ ) of core PE252-32, revealing the major increase in $\mathrm{Hg}, \mathrm{Pb}$ and $\mathrm{Zn}$ concentrations indicative of anthropogenic contributions. This cluster can be divided into two subgroups $\left(1_{\mathrm{A}}\right.$ and $\left.1_{\mathrm{B}}\right)$. Subgroup $1_{\mathrm{A}}$ is composed of samples showing a homogeneous increase in $\mathrm{Hg}, \mathrm{Pb}$ and $\mathrm{Zn}$ concentrations, while the subgroup $1_{B}$ includes the most recent samples containing the highest concentrations of these elements. Cluster 2 represents the pre-industrial samples. Subgroup 2 includes the sample depths characterized by the lowest $\mathrm{Hg}, \mathrm{Pb}$ and $\mathrm{Zn}$ contents and the highest $\mathrm{Si}$ and $\mathrm{Ca}$ contents in conjunction with relatively sandy sediments. These coarse sediments may have diluted $\mathrm{Hg}, \mathrm{Pb}$ and $\mathrm{Zn}$ concentrations. Sample depths marked by the increase in fine-grained sizes are grouped in $2_{\mathrm{B}}$.
In this subgroup, samples show a slight increase in $\mathrm{Hg}$, $\mathrm{Pb}$ and $\mathrm{Zn}$ contents, concomitant with increasing concentrations of $\mathrm{Al}$ and $\mathrm{Li}$, elements associated with the fine-grained sediment components.

\section{DISCUSSION}

\section{Natural vs. anthropogenic variability}

To compensate for grain-size variations, total metal contents are commonly normalized using $\mathrm{Al}$ or $\mathrm{Li}$ as a proxy for the fine-grained fraction (Loring and Rantala, 1992). Both elements are present in the lattice of fine-grained aluminosilicate minerals and are not substantially influenced by anthropogenic activities (Windom et al., 1989; Loring and Rantala, 1992). Prior to $1900 \mathrm{AD}$ (underneath the $10 \mathrm{~cm}$ core depth), despite the similar trends of $\mathrm{Li}$ and $\mathrm{Al}$ and the fine fraction (Figs. 2 and 3) and metals $(\mathrm{Cu}, \mathrm{Cr}, \mathrm{Ni}, \mathrm{Hg}, \mathrm{Pb}$ and $\mathrm{Zn}), \mathrm{Al}$ shows higher regression coefficients $\left(r^{2}\right)$ with metals than Li (Fig. 4). Thus, Al seems to be a better geochemical normalizer for explaining the natural variability in metal concentrations. The regular down-core normalized profile of $\mathrm{Cr}$ suggests a detrital origin for this element (Fig. 8), agreeing with the results of cluster analysis (Fig. 6). The normalized profiles of $\mathrm{Cu}, \mathrm{Zn}$, $\mathrm{Pb}$ and $\mathrm{Hg}$ exhibit approximately constant values prior to AD 1900, suggesting that slight changes in metal concentrations (Fig. 3) are grain-size dependent. After this period, normalized profiles of $\mathrm{Hg}, \mathrm{Pb}$ and $\mathrm{Zn}$ show a gradual increase up to AD 1980 (2 cm core depth), followed by a slight decrease towards the present-day (surface sample) (Fig. 8). These variations in normalized metal contents, unrelated to grain-size variation, probably reflect predominantly anthropogenic contributions derived from the intense industrial and urban activities in the Tagus estuary.

Although the normalized profile of $\mathrm{Cu}$ for the last 100 years (top 10 centimetres) displays an increasing trend, a marked peak stands out at AD $1981(3.5 \mathrm{~cm})$, below or coincident with the peaks of $\mathrm{Mn}(1.5 \mathrm{~cm}$; Fig. 3) and $\mathrm{Fe}$ (2.5 - $3.5 \mathrm{~cm}$; Fig. 3). The existence of metal peaks such as that of $\mathrm{Cu}$ at, or near, the redox boundary, and to a lesser extent that of $\mathrm{Ni}$, suggests an association with other mineral phases (such as oxide/ hydroxides of $\mathrm{Fe}$ and $\mathrm{Mn}$ ) and hence a connection with diagenetic processes and metal redistribution (Thomson et al., 1996, 1998). This is also indicated by the $\mathrm{Cu}$ and Ni clustering with Fe (Fig. 6, subgroup $\mathrm{A}_{1.2}$ ) and with Mn (Fig. 6, subgroup $\mathrm{A}_{2}$ ).

\section{Estimation of anthropogenic enrichments}

Anthropogenic enrichments were only estimated for $\mathrm{Hg}, \mathrm{Pb}$ and $\mathrm{Zn}$ following the output grouping obtained by the cluster analysis. They were estimated through the determination of EF.

In this study, background values were obtained from the average contents of the three deeper sam- 


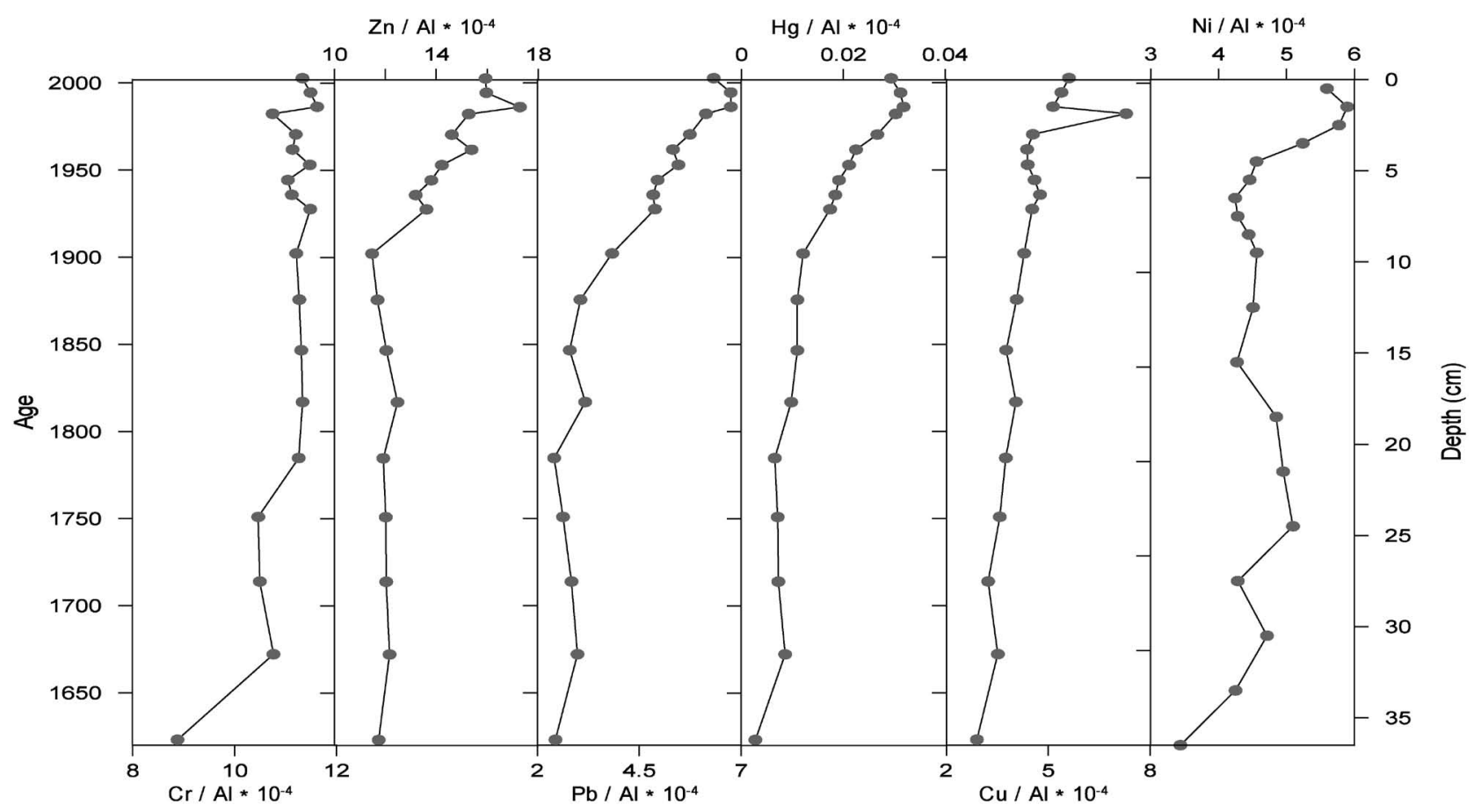

FIG. 8. - Vertical profiles of metal $(\mathrm{Cr}, \mathrm{Cu}, \mathrm{Hg}, \mathrm{Ni}, \mathrm{Pb}$ and $\mathrm{Zn})$ to $\mathrm{Al}$ ratios in multi-core $\mathrm{PE} 252-32$. Chronology is derived from ${ }^{210} \mathrm{~Pb}$. The extrapolation of ${ }^{210} \mathrm{~Pb}$ chronology to ages of $1650 \mathrm{AD}$ is done assuming constant sediment accumulation rates.

ples that are considered as representing the local pre-industrial values. Based on the ${ }^{210} \mathrm{~Pb}$ chronology, and using the calculated sediment accumulation rate of $0.061 \mathrm{~g} \mathrm{~cm}^{-2} \mathrm{yr}^{-1}$, the three bottom samples of the core fall within the interval between AD 1728 and AD 1674. As the underlying assumption of constant sediment accumulation rates throughout the record cannot be tested, we only show EF values of $\mathrm{Hg}, \mathrm{Pb}$

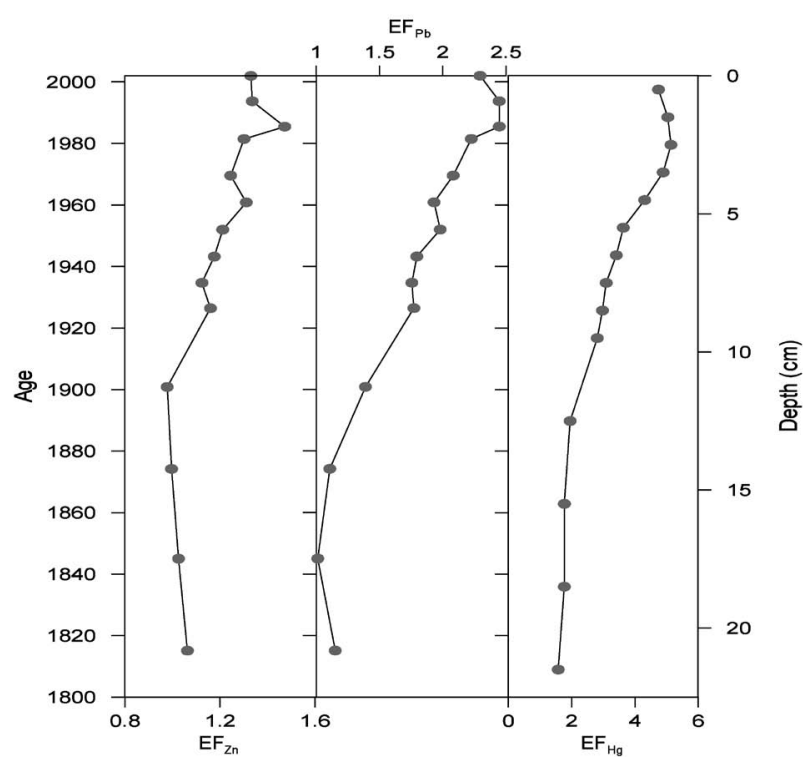

FIG. 9. - Historical trends in normalized enrichment factors for $\mathrm{Hg}$, $\mathrm{Pb}$ and $\mathrm{Zn}$. EFs are calculated by dividing the $\mathrm{Al}$-normalized metal contents by the Al-normalized metal background for each core. Samples older than $1800 \mathrm{AD}$ are not represented. and $\mathrm{Zn}$ for samples younger than $\mathrm{AD} 1800$ (Figure 9). The EF for the three elements shows quite constant values until the beginning of the $20^{\text {th }}$ century. Thereafter we observe an increasing trend until the middle of the 1980s followed by a slight decrease in metal enrichments (Fig. 9). Mercury reaches the highest level of enrichment $\left(\mathrm{EF}_{\mathrm{Hg}(\max )}=5\right)$, followed by $\mathrm{Pb}$ and $\mathrm{Zn}$. Enrichments are lower than in finegrained deposit of the Tagus prodelta $\left(\mathrm{EF}_{\mathrm{Hg}(\max )}=20\right.$; $\left.\mathrm{EF}_{\mathrm{Pb}(\max )}=7 ; \mathrm{EF}_{\mathrm{Zn}(\max )}=4\right)$ (Mil-Homens et al., 2009a), reflecting both the greater distance to the source of contaminated sediments (the Tagus estuary) and dilution with marine uncontaminated sediment. On the other hand, the same order of enrichment was found in a depocentre located to the north of the Nazare Canyon (Mil-Homens et al., 2008).

\section{CONCLUSIONS}

The temporal evolution of anthropogenic metal enrichment trends between the 1900s and the 1980s is comparable between the Tagus prodelta and site PE252-32 in the Cascais Canyon. Though sediment accumulation rate in the canyon is approximately 3 times lower than on the Tagus prodelta, the similarity of anthropogenic enrichment trends reveals an efficient transfer of contaminated sediments from the shelf to $2100 \mathrm{~m}$ water depth within the Cascais Canyon. The results prove that this sector of the canyon acts as a sink of contaminated sediments, extending the negative effects of contamination to deep regions of the Portuguese Margin. 


\section{ACKNOWLEDGEMENTS}

Most of this work was supported by the PDCT/ MAR/56781/2004 CANYONS project, funded by Fundação para a Ciência e a Tecnologia, Portugal. Multi-core PE252-32 was collected by the Royal Netherlands Institute for Sea Research (NIOZ), within the project "Lead in Canyons" (contract 814.01.018 of the Netherlands Organization for Scientific Research (NWO)) and HERMES - Hotspot Ecosystem Research on the Margins of European Seas (contract GOCECT-2005-511234 of the EC). We thank the technical laboratory support given at NIOZ (the Netherlands), and LNEG-UGM and LNEG-LAQ (Portugal).

\section{REFERENCES}

Alves, S., M. Santos and M. Trancoso. - 2009. Evaluation of measurements uncertainties for the determination of total metal content in soils by atomic absorption spectrometry. Accred. Qual. Assur., 14: 87-93.

Appleby, P. and F. Oldfield. - 1992. Applications of lead-210 to sedimentation studies. In: M. Ivanovich and R.S. Harmon (eds.), Uranium Series Disequilibrium. Applications to Earth, Marine and Environmental Sciences, pp. 731-778. Clarendon Press, Oxford.

Araújo, F., T. Pinheiro, L.C. Alves, P. Valerio, F. Gaspar and J. Alves. - 1998. Elemental composition in sediments and water in the Trancao river basin. A preliminary study. Nuclear Instruments and Methods in Physics Research Section B: Beam Interactions with Materials and Atoms, 136-138: 1005-1012.

Arzola, R.G., R.B. Wynn, G. Lastras, D.G. Masson and P.P.E. Weaver. - 2008. Sedimentary features and processes in the Nazaré and Setúbal submarine canyons, west Iberian margin. Mar. Geol., 250: 64-88.

Boer, W., G.D. van den Bergh, H. de Haas, H.C. de Stigter, R. Gieles and T.C.E. van Weering. - 2006. Validation of accumulation rates in Teluk Banten (Indonesia) from commonly applied ${ }^{210} \mathrm{~Pb}$ models, using the 1883 Krakatau tephra as time marker. Mar. Geol., 227: 263-277.

Canário, J., C. Vale and M. Caetano. - 2005. Distribution of monomethylmercury and mercury in surface sediments of the Tagus Estuary (Portugal). Mar. Pollut. Bull., 50: 1142-1145.

Costley, C.T., K.F. Mossop, J.R. Dean, L.M. Garden, J. Marshall and J. Carroll. - 2000. Determination of mercury in environmental and biological samples using pyrolysis atomic absorption spectrometry with gold amalgamation. Anal. Chim. Acta, 405: 179-183.

Cundy, A. and I. Croudace. - 1995. Sedimentary and geochemical variations in a salt marsh/mud flat environment from the mesotidal Hamble estuary, southern England. Mar. Chem., 51: 115-132.

Davis, J.C. - 2002. Statistics and data analysis in geology. John Wiley \& Sons, New York.

de Stigter, H.C., W. Boer, P.A. de Jesus Mendes, C.C. Jesus, L. Thomsen, G.D. van den Bergh and T.C.E. van Weering. -2007. Recent sediment transport and deposition in the Nazare Canyon, Portuguese continental margin. Mar. Geol., 246: 144-164.

Ferrand, J.-L., B. Hamelin and A. Monaco. - 1999. Isotopic tracing of anthropogenic $\mathrm{Pb}$ inventories and sedimentary fluxes in the Gulf of Lions (NW Mediterranean sea). Cont. Shelf Res., 19: 23-47.

Figuères, G., J. Martin, M. Meybeck and P. Seyler. - 1985. A comparative study of mercury contamination in the Tagus estuary (Portugal) and major French estuaries (Gironde, Loire, Rhone). Estuar. Coast. Shelf Sci., 20: 183-203.

Jouanneau, J.-M., C. Garcia, A. Oliveira, A. Rodrigues, J. Dias and O. Weber. - 1998. Dispersal and deposition of suspended sediment on the shelf off the Tagus and Sado estuaries, SW Portugal. Prog. Oceanogr., 42: 233-257.

Lastras, G., R.G. Arzola, D.G. Masson, R.B. Wynn, V.A.I. Huvenne,
V. Hühnerbach and M. Canals. - 2009. Geomorphology and sedimentary features in the Central Portuguese submarine canyons, Western Iberian margin. Geomorphology, 103: 310-329.

Loring, D. and R. Rantala. - 1992. Manual for the geochemical analyses of marine sediments and suspended particulate matter. Earth Sci. Rev., 32: 235-283.

Mil-Homens, M., V. Branco, C. Vale, R. Stevens, W. Boer, S. Lebreiro, I. Cato and F. Abrantes. - 2008. Historical trends in $\mathrm{Hg}$, $\mathrm{Pb}$ and $\mathrm{Zn}$ sedimentation in the central shelf area of Portugal. $J$. Iber. Geol., 34: 272-286.

Mil-Homens, M., V. Branco, C. Vale, W. Boer, U. Alt-Epping, F. Abrantes and M. Vicente. - 2009a. Sedimentary record of anthropogenic metal inputs in the Tagus prodelta (Portugal). Cont. Shelf Res., 29: 381-392.

Mil-Homens, M., V. Branco, C. Lopes, C. Vale, F. Abrantes, W. Boer and M. Vicente. - 2009b. Using Factor Analysis to Characterise Historical Trends of Trace Metal Contamination in a Sediment Core from the Tagus Prodelta, Portugal. Water Air Soil Pollut., 197: 277-287.

Paiva, P., J.-M. Jouanneau, F. Araújo, O. Weber, A. Rodrigues and J. Dias. - 1997. Chemical characterisation of the sedimentary formation on the Portuguese shelf adjacent to Tagus river. Water Air Soil Pollut., 99: 507-514.

Palanques, A., J. Martín, P. Puig, J. Guillén, J.B. Company and F. Sardà. - 2006. Evidence of sediment gravity flows induced by trawling in the Palamós (Fonera) submarine canyon (northwestern Mediterranean). Deep Sea Res. I, 53: 201-214.

Palanques, A., P. Masque, P. Puig, J.A. Sanchez-Cabeza, M. Frignani and F. Alvisi. - 2008. Anthropogenic trace metals in the sedimentary record of the Llobregat continental shelf and adjacent Foix Submarine Canyon (northwestern Mediterranean). Mar. Geol., 248: 213-227.

Paull, C., H. Greene, W. Ussler III and P. Mitts. - 2002. Pesticides as tracers of sediment transport through Monterey Canyon, Geo-Mar. Lett., 22: 121-126.

Queralt, I., M. Barreiros, M. Carvalho and M. Costa. - 1999. Application of different techniques to assess sediment quality and point source pollution in low-level contaminated estuarine recent sediments (Lisboa coast, Portugal). Sci. Total Environ., 241: 39-51.

Richter, T.O., H.C. de Stigter, W. Boer, C.C. Jesus and T.C.E. van Weering. - 2009. Dispersal of natural and anthropogenic lead through submarine canyons at the Portuguese margin. Deep Sea Res. I, 56: 267-282.

Robbins, J. - 1978. Geochemical and geophysical application of radoactive lead. In: J. Nriagu (ed.), The biogeochemistry of lead in the environment, pp. 285-393. Elsevier/North-Holland Biomedical Press, Amsterdam.

Thomson, J., N.C. Higgs and S. Colley. - 1996. Diagenetic redistributions of redox-sensitive elements in northeast Atlantic glacial/interglacial transition sediments. Earth Planet. Sci. Lett., 139: 365-377.

Thomson, J., I. Jarvis, D.R.H. Green, D.A. Green and T. Clayton. - 1998. Mobility and immobility of redox-sensitive elements in deep-sea turbidites during shallow burial. Geochim. Cosmochim. Acta, 62: 643-656.

Vale, C. - 1990. Temporal variations of particulate metals in the Tagus River estuary. Sci. Total Environ., 97-98: 137-154.

Vale, C., J. Canário, M. Caetano, J. Lavrado and P. Brito. - 2008. Estimation of the anthropogenic fraction of elements in surface sediments of the Tagus Estuary (Portugal). Mar. Pollut. Bull., 56: $1364-1367$.

Valette-Silver, N. - 1993. The use of sediment cores to reconstruct historical trends in contamination of estuarine and coastal sediments. Estuaries, 16: 577-588.

van Weering, T., H. de Stigter, W. Boer and H. de Haas. - 2002. Recent sediment transport and accumulation on the NW Iberian margin. Prog. Oceanogr., 52: 349-371.

Windom, H., S. Schropp, F. Calder, J. Ryan, R. Smith, L. Burney, F. Lewis and C. Rawlinson. - 1989. Natural trace metal concentrations in estuarine and coastal marine sediments of the southeastern United States. Environ. Sci. Technol., 23: 314-320.

Received November 1, 2008. Accepted July 26, 2010.

Published online November 13, 2010. 